\title{
PERBANDINGAN PENINGKATAN KEMAMPUAN PENALARAN MATEMATIS ANTARA PEMBELAJARAN BERBASIS MASALAH DAN PENEMUAN TERBIMBING DITINJAU DARI KEMAMPUAN AWAL MATEMATIS SISWA
}

\author{
Marfi Ario \\ Universitas Pasir Pengaraian \\ marfi.ario.92@gmail.com
}

\begin{abstract}
Mathematical reasoning ability is fundamental aspect in mathematic learning. Efforts to improve the ability of mathematical reasoning necessary. Based on that, this study was conducted to examine improvement of mathematical reasoning ability students who received problem based learning and guided discovery learning in terms of categories Early Mathematical Ability (EMA) students. This study was a quasi experimental research with the pretest-post-tes two treatment design. The population in this study were the students in class XI from one of SMK in Pekanbaru. Samples in this study were 76 students from two classes using purposive sampling technique. Instrument that used in this study was the questions of mathematical reasoning ability test. The findings of this study are: there is a difference in the improvement of mathematical reasoning ability among students who get problem based learning and students who gain guided discovery learning on medium KAM category students. In high and low KAM category students, there is no significant difference in the improvement of mathematical reasoning abilities between students who received problem based learning and students who received guided discovery learning.
\end{abstract}

Keywords : Mathematical reasoning, Problem based learning, Guided discovery learning, EMA

\section{PENDAHULUAN}

Tujuan umum pembelajaran matematika salah satunya adalah supaya siswa belajar bernalar matematis (NCTM, 1989). Selanjutnya NCTM (2000) menyatakan bahwa standar proses pembelajaran matematika terdiri dari pemecahan masalah, penalaran dan pembuktian, komunikasi, koneksi, dan representasi. Sejalan dengan itu, tujuan pembelajaran matematika yang dinyatakan oleh BSNP (2006) salah satunya yaitu agar peserta didik menggunakan penalaran pada pola dan sifat.

Penetapan kemampuan penalaran sebagai tujuan dan standar proses dari pembelajaran matematika merupakan sebuah bukti bahwa kemampuan penalaran sangat penting untuk dimiliki siswa. Hal ini diperkuat oleh pendapat beberapa ahli yang menyatakan bahwa kemam puan penalaran sangat penting dan merupakan aspek fundamental untuk memahami mate matika (Wahyudin, 2008; Turmudi, 2008; Sumarmo, 2013).

Memperhatikan pendapat ahli di atas, dapat kita simpulkan bahwa penalaran meru pakan hal yang sangat penting dalam belajar matematika. Oleh karena itu, sudah seharusnya siswa memiliki kemampuan penalaran mate matis yang baik. Akan tetapi, fakta di lapangan menunjukkan hal yang berbeda. Kemampuan penalaran matematis siswa di sekolah masih rendah. Hasil penelitian Yuniati (2010) dan Sentosa (2013) menunjukkan pencapaian kemampuan penalaran matematis siswa masih dibawah 50\%. Tidak hanya di tingkat sekolah, rendahnya kemampuan penalaran matematis bahkan juga dialami oleh mahasiswa jurusan matematika di perguruan tinggi. Salah satunya sebagaimana yang diungkapkan Armiati (2011) dari studi pendahuluannya yang menunjukkan indikasi lemahnya penalaran matematis mahasiswa.

Selain hasil penelitian di atas, juga dila kukan studi pendahuluan di salah satu sekolah menengah kejuruan (SMK) di Pekanbaru. Diberikan 2 soal penalaran kepada 72 siswa yang berasal dari kelas XI dan XII. Soal 1 meminta siswa untuk menjustifikasi suatu argu men. Soal 2 merupakan soal non-rutin yang menuntut siswa untuk menganalisis informasi yang ada dan menyelesaikan permasalahan pada soal. Hasil studi pendahuluan ini, hanya 4 siswa yang menjawab benar untuk Soal 1. Sedangkan soal 2, hanya 3 siswa yang menjawab benar. 
Hasil ini menunjukkan bahwa kemampuan penalaran siswa masih sangat rendah.

Mengetahui fakta tentang rendahnya kemampuan penalaran matematis siswa, serta pentingnya kemampuan penalaran matematis, maka upaya peningkatan kemampuan penalaran matematis harus dilakukan baik oleh guru maupun praktisi pendidikan lainnya. Upaya yang dapat dilakukan diantaranya adalah dengan memperbaiki proses pembelajaran melalui pemi lihan model pembelajaran yang digunakan. Bebe rapa model pembelajaran yang direkomen dasikan oleh para ahli maupun peneliti adalah Pembelajaran Berbasis Masalah (PBM) dan Pembelajaran Penemuan Terbimbing (PPT).

Karakter PBM dan PPT sama-sama menuntut siswa untuk aktif dalam membangun pengetahuannya sendiri. Dalam prakteknya, pada kedua model pembelajaran ini, siswa akan dikelompokkan untuk berdiskusi bersama teman-temannya dalam memecahkan masalah ataupun menemukan konsep. Siswa akan saling bertukar pendapat, menerima dan membantah argumen temannya, menyusun konjektur, hingga bersepakat dalam membuat keputusan akhir sebagai hasil kerja kelompok. Proses pem belajaran seperti ini dapat menumbuhkan kemampuan penalaran matematis. Hal ini sesuai dengan yang disampaikan oleh Wahyudin (2008) bahwa ruang-ruang kelas dimana para siswa didorong untuk menyampaikan pemikiran mereka dan setiap orang berperan serta dengan saling mengevaluasi pemikiran mereka, akan memberikan lingkungan-lingkungan yang kaya untuk belajar bernalar matematis.

Beberapa studi antara lain Herman (2007), Buhaerah (2011), Padmavathy \& Mareesh (2013) dan Ajai, dkk. (2013), mela porkan keunggulan pembelajaran berbasis masalah daripada pembelajaran konvensional dalam mengembangkan beragam kemampuan matematis. Beberapa studi lain diantaranya: Effendi (2012), Nurcholis (2013), Purwatiningsi (2013), dan Hasibuan (2014), juga melaporkan keunggulan pembelajaran penemuan terbimbing daripada pembelajaran konvensional dalam mengembangkan beragam kemampuan mate matis. Selain itu, beberapa studi dengan pembelajaran yang beragam diantaranya: Kramarski \& Mevarech (2003) dan Rahmatudin (2013), melaporkan bahwa melalui beragam pendekatan pembelajaran inovatif, siswa mencapai kemampuan penalaran yang lebih baik dibandingkan siswa dengan pembelajaran konvensional.

Berdasarkan karakter PBM dan PPT beserta hasil temuan penelitian sebelumnya, diduga bahwa kemampuan penalaran matematis siswa dapat ditingkatkan melalui penerapan pembelajaran berbasis masalah dan pem belajaran penemuan terbimbing. Selain model pembelajaran, faktor lain yang turut mem pengaruhi kemampuan penalaran matematis siswa adalah Kemampuan Awal Matematis (KAM) siswa. Hal ini disebabkan karena karakter matematika yang merupakan ilmu hierarki. Setiap konsep memerlukan konsepkonsep sebelumnya. Oleh karena itu kemam puan awal siswa sangat penting dalam menen tukan pencapaian siswa pada materi berikutnya. Berdasarkan hal tersebut, penelitian ini dilakukan dengan tujuan untuk menelaah peningkatan kemampuan penalaran matematis antara siswa yang mendapat pembelajaran berbasis masalah dengan siswa yang mendapat pembelajaran penemuan terbimbing ditinjau dari KAM siswa.

\section{METODE PENELITIAN}

Penelitian ini merupakan quasi experiment dengan desain the pretest-post-tes two treatment design (Cohen, et all., 2007). Kelas eksperimen 1 diberikan pembelajaran berbasis masalah dan kelas eksperimen 2 diberikan pembelajaran penemuan terbimbing. Populasi dalam penelitian ini adalah seluruh siswa kelas XI salah satu SMK swasta di Kota Pekanbaru yang terdiri dari enam kelas. Sampel pada penelitian ini adalah 76 siswa dari 2 kelas yang diambil dengan teknik purposive sampling.

Sampel di kedua kelas eksperimen masing-masing dibagi berdasarkan kategori Kemampuan Awal Matematis (KAM) siswa yaitu kelompok tinggi, sedang, dan rendah. Skor yang digunakan untuk menentukan kategori KAM siswa diperoleh dari beberapa nilai ulangan harian siswa.

Instrumen pengumpul data pada pene litian ini adalah tes berupa soal uraian untuk mengukur kemampuan penalaran matematis siswa. Sebelum digunakan, tes diuji validitas dan reliabilitasnya terlebih dahulu. Validitas tes pada penelitian ini diukur menggunakan rumus korelasi product moment pearson dan derajat reliabilitas dihitung dengan rumus cronbachalpha (Arikunto, 2013). Setelah memenuhi 
syarat validitas dan reliabilitas, tes kemudian digunakan sebagai instrumen pada penelitian ini.

Data hasil penelitian tentang kemampuan penalaran matematis dianalisis menggunakan statistik deskriptif dan statistik inferensial. Statistik deskriptif dari data disajikan dalam bentuk tabel. Analisis menggunakan statistik inferensial dilakukan untuk melihat perbedaan kemampuan penalaran matematis antara siswa yang memperoleh pembelajaran berbasis masalah dan siswa yang memperoleh pembelajaran penemuan terbimbing pada masing-masing KAM siswa.

\section{HASIL DAN PEMBAHASAN}

Hasil penelitian tentang kemampuan penalaran matematis siswa diperoleh dari data hasil pretes dan postes. Dari hasil pretes dan postes, dihitung Gain ternormalisasi ( $N$-gain) kemampuan penalaran matematis dengan rumus berikut (Meltzer, 2002):

$$
N \text {-gain }=\frac{\text { skor postes-skor pretes }}{\text { skor ideal-skor pretes }}
$$

Kriteria skor $\mathrm{N}$-gain ditentukan sebagai berikut (Hake, 1999):

Tinggi : $N$-gain $>0,7$

Sedang: $0,3 \leq N$-gain $\leq 0,7$

Rendah: $N$-gain $\leq 0,3$

Statistik deskriptif mengenai skor pretes, postes, dan N-gain diuraikan pada Tabel 1. Dalam hal ini skor ideal pretes adalah 27.

Tabel 1. Statistik Deskriptif Skor Pretes

\begin{tabular}{|l|l|l|l|l|l|}
\hline Kelas & KAM & $\mathrm{N}$ & $\bar{x}$ & $\%$ & SD \\
\hline \multirow{4}{*}{ PBM } & Tinggi & 6 & 5,00 & 18,52 & 3,69 \\
\cline { 2 - 6 } & Sedang & 22 & 4,64 & 17,17 & 3,81 \\
\cline { 2 - 6 } & Rendah & 10 & 2,80 & 10,37 & 1,62 \\
\cline { 2 - 6 } & Total & $\mathbf{3 8}$ & $\mathbf{4 , 2 1}$ & $\mathbf{1 5 , 6 0}$ & $\mathbf{3 , 3 9}$ \\
\hline \multirow{4}{*}{ PPT } & Tinggi & 6 & 6,33 & 23,46 & 5,47 \\
\cline { 2 - 6 } & Sedang & 29 & 3,28 & 12,13 & 2,07 \\
\cline { 2 - 6 } & Rendah & 3 & 2,33 & 8,64 & 0,58 \\
\cline { 2 - 6 } & Total & $\mathbf{3 8}$ & $\mathbf{3 , 6 8}$ & $\mathbf{1 3 , 6 5}$ & $\mathbf{2 , 9 5}$ \\
\hline
\end{tabular}

Berdasarkan Tabel 1, skor rata-rata kelas PBM secara keseluruhan lebih tinggi 0,53 poin atau $1,95 \%$ daripada kelas PPT. Perbedaan ratarata $1,95 \%$ ini sangat kecil sehingga dapat dikatakan bahwa skor pretes kedua kelas hampir sama. Dilihat dari nilai simpangan bakunya, skor pretes siswa di kelas PBM lebih menyebar dibandingkan skor siswa di kelas PPT.

Jika dilihat berdasarkan kategori KAM siswa, nilai pretes kelas PBM lebih tinggi dibandingkan kelas PPT pada siswa kategori
KAM sedang dan rendah. Sedangkan pada kategori KAM tinggi, siswa di kelas PPT lebih tinggi dibandingkan kelas PBM. Perbedaan skor pretes pada setiap KAM siswa antara kelas PBM dan PPT tidak lebih dari 6\%.

Statistik deskriptif data skor postes dapat dilihat pada Tabel 2. Dalam hal ini skor ideal pretes adalah 27.

Tabel 2. Statistik Deskriptif Skor Postes

\begin{tabular}{|l|l|l|l|l|l|}
\hline Kelas & KAM & $\mathrm{N}$ & $\bar{x}$ & $\%$ & $\mathrm{~s}$ \\
\hline \multirow{4}{*}{ PBM } & Tinggi & 6 & 22,50 & 83,33 & 5,24 \\
\cline { 2 - 6 } & Sedang & 22 & 21,36 & 79,12 & 3,40 \\
\cline { 2 - 6 } & Rendah & 10 & 14,80 & 54,81 & 5,73 \\
\cline { 2 - 6 } & Total & $\mathbf{3 8}$ & $\mathbf{1 9 , 8 2}$ & $\mathbf{7 3 , 3 9}$ & $\mathbf{5 , 2 6}$ \\
\hline \multirow{4}{*}{ PPT } & Tinggi & 6 & 18,83 & 69,75 & 3,60 \\
\cline { 2 - 6 } & Sedang & 29 & 14,79 & 54,79 & 5,60 \\
\cline { 2 - 6 } & Rendah & 3 & 8,00 & 29,63 & 4,36 \\
\cline { 2 - 6 } & Total & $\mathbf{3 8}$ & $\mathbf{1 4 , 8 9}$ & $\mathbf{5 5 , 1 7}$ & $\mathbf{5 , 7 4}$ \\
\hline
\end{tabular}

Berdasarkan Tabel 2, rata-rata skor postes kelas PBM secara keseluruhan lebih tinggi 4,93 poin atau $18,22 \%$ daripada kelas PPT. Selisih skor ini dapat dikatakan cukup tinggi. Dilihat dari nilai simpangan bakunya, skor pada kelas PPT lebih menyebar daripada kelas PBM. Berdasarkan deskripsi skor postes, dapat dikatakan bahwa skor postes kelas PBM lebih tinggi daripada kelas PPT.

Jika dilihat berdasarkan kategori KAM siswa, nilai postes siswa di kelas PBM lebih tinggi dibandingkan siswa di kelas PPT pada semua kategori KAM. Siswa KAM tinggi pada kelas PPT yang awalnya memiliki skor pretes yang lebih tinggi dari siswa kelas PBM, ketika postes ternyata lebih rendah dibandingkan siswa kelas PBM.

Berdasarkan skor pretes dan postes, ditentukan skor peningkatan ( $N$-gain) kemam puan penalaran matematis siswa. Statistik deskriptif mengenai skor $N$-gain dapat dilihat pada Tabel 3. Dalam hal ini skor ideal $N$-gain adalah 1 .

Tabel 3. Statistik Deskriptif Skor $N$-gain

\begin{tabular}{|l|l|l|l|l|l|}
\hline Kelas & KAM & $\mathrm{N}$ & $\bar{x}$ & $\%$ & $\mathrm{~s}$ \\
\hline \multirow{4}{*}{ PBM } & Tinggi & 6 & 0,81 & 81 & 0,21 \\
\cline { 2 - 6 } & Sedang & 22 & 0,75 & 75 & 0,15 \\
\cline { 2 - 6 } & Rendah & 10 & 0,50 & 50 & 0,23 \\
\cline { 2 - 6 } & Total & $\mathbf{3 8}$ & $\mathbf{0 , 6 9}$ & $\mathbf{6 9}$ & $\mathbf{0 , 2 1}$ \\
\hline \multirow{4}{*}{ PPT } & Tinggi & 6 & 0,62 & 62 & 0,11 \\
\cline { 2 - 6 } & Sedang & 29 & 0,49 & 49 & 0,22 \\
\cline { 2 - 6 } & Rendah & 3 & 0,23 & 23 & 0,17 \\
\cline { 2 - 6 } & Total & $\mathbf{3 8}$ & $\mathbf{0 , 4 9}$ & $\mathbf{4 9}$ & $\mathbf{0 , 2 2}$ \\
\hline
\end{tabular}


Berdasarkan Tabel 3, rata-rata skor $\mathrm{N}$ gain pada kelas PBM secara keseluruhan lebih tinggi 0,20 poin atau $20 \%$ dibandingkan kelas PPT. Penyebaran skor $N$-gain pada kedua kelas hampir sama. Hal ini dilihat dari nilai sim pangan baku skor $\mathrm{N}$-gain yang hanya berbeda 0,01 . Dilihat dari kategori peningkatan kemam puan penalaran matematis, kedua kelas termasuk pada kategori sedang.

Jika dilihat berdasarkan KAM siswa, peningkatan kemampuan penalaran matematis siswa kelas PBM lebih tinggi daripada siswa kelas PPT pada setiap kategori KAM. Jika disajikan dalam bentuk diagram, rata-rata skor $\mathrm{N}$-gain untuk setiap kategori KAM dari kedua kelas eksperimen dapat dilihat pada gambar berikut.

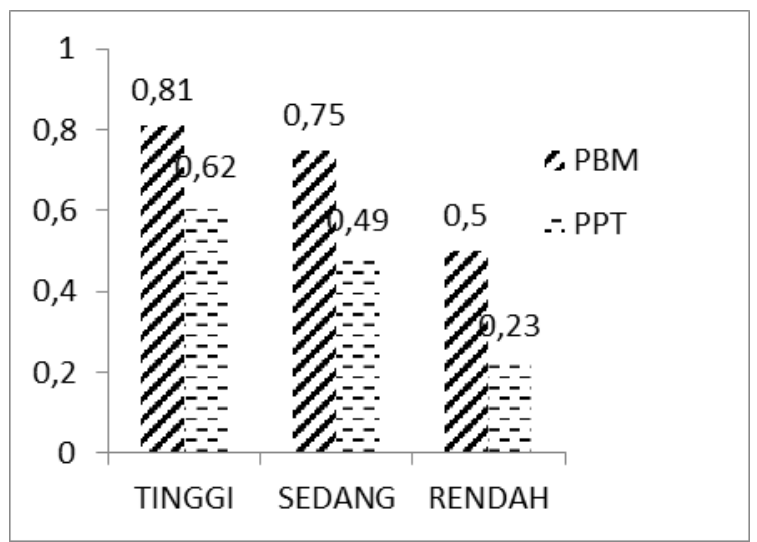

Gambar 1. Diagram Rata-rata Skor N-gain

Diagram di atas menunjukkan bahwa pada setiap kategori KAM, peningkatan kemampuan penalaran matematis siswa yang mendapat pembelajaran berbasis masalah lebih baik daripada siswa yang mendapat pem belajaran penemuan terbimbing. Selisih pening katan kemampuan penalaran matematis siswa KAM tinggi kelas PBM dengan siswa KAM tinggi kelas PPT yaitu sebesar 0,19 (19\%). Sedangkan pada siswa KAM sedang dan KAM rendah berturut-turut sebesar 0,26 (26\%) dan 0,27 (27\%). Peningkatan kemampuan penalaran matematis siswa KAM sedang di kelas PBM lebih tinggi daripada peningkatan kemampuan penalaran matematis siswa KAM tinggi di kelas PPT dengan selisih 0,13 (13\%).

Uji statistik dilakukan untuk menentukan apakah terdapat perbedaan signifikan pening katan kemampuan penalaran matematis antara siswa pada kelas PBM dengan siswa pada kelas PPT pada masing-masing KAM siswa. Uji dilakukan terhadap dua data, yaitu data pretes dan data $N$-gain. Uji terhadap skor pretes dilakukan untuk mengetahui apakah kedua kelas eksperimen memiliki kemampuan awal yang sama atau tidak. Uji terhadap skor $N$-gain dilakukan untuk mengetahui apakah pening katan skor kemampuan penalaran matematis antara kedua kelas eksperimen berbeda secara signifikan atau tidak.

Uji normalitas skor pretes dihitung menggunakan uji One-Sampel KolmogorovSmirnov dengan nilai $\alpha=0,05$. Hasil perhi tungan uji normalitas disajikan pada Tabel 4.

Tabel 4. Hasil Uji Normalitas Skor Pretes

\begin{tabular}{|c|l|c|c|c|}
\hline \multirow{2}{*}{ KAM } & \multirow{2}{*}{ Kelas } & \multicolumn{2}{|c|}{$\begin{array}{c}\text { One-Sampel } \\
\text { Kolmogorov- } \\
\text { Smirnov }\end{array}$} & \multirow{2}{*}{ Kesimpulan } \\
\cline { 3 - 4 } & & Stat & Sig. & \\
\hline \multirow{2}{*}{ Tinggi } & PBM & 0,670 & 0,760 & $\mathrm{H}_{0}$ diterima \\
\cline { 2 - 4 } & PPT & 0,468 & 0,981 & $\mathrm{H}_{0}$ diterima \\
\hline \multirow{2}{*}{ Sedang } & PBM & 1,164 & 0,133 & $\mathrm{H}_{0}$ diterima \\
\cline { 2 - 4 } & PPT & 1,121 & 0,162 & $\mathrm{H}_{0}$ diterima \\
\hline \multirow{2}{*}{ Rendah } & PBM & 0,915 & 0,372 & $\mathrm{H}_{0}$ diterima \\
\cline { 2 - 5 } & PPT & 0,667 & 0,766 & $\mathrm{H}_{0}$ diterima \\
\hline
\end{tabular}

Tabel di atas menunjukkan bahwa data skor pretes kemampuan penalaran matematis siswa pada semua kategori KAM di kedua kelas eksperimen berdistribusi normal. Analisis selan jutnya yaitu uji homogenitas. Uji homogenitas dilakukan menggunakan uji homogeneity of variances (leverne statistic) dengan nilai $\alpha=$ 0,05 . Hasil perhitungan uji homogenitas disajikan pada tabel dibawah ini dengan kesimpulan bahwa data skor pretes kemampuan penalaran matematis pada kategori KAM tinggi, sedang, dan rendah masing-masing memiliki variansi yang homogen.

Tabel 5. Hasil Uji Homogenitas Skor Pretes

\begin{tabular}{|l|c|c|l|}
\hline KAM & $\begin{array}{l}\text { Levene } \\
\text { Statistic }\end{array}$ & Sig. & Kesimpulan \\
\hline Tinggi & 0,854 & 0,377 & $\mathrm{H}_{0}$ diterima \\
\hline Sedang & 3,311 & 0,075 & $\mathrm{H}_{0}$ diterima \\
\hline Rendah & 1,170 & 0,302 & $\mathrm{H}_{0}$ diterima \\
\hline
\end{tabular}

Uji selanjutnya menggunakan uji statistik parametrik, yaitu uji-t dengan nilai $\alpha=0,05$. Hasil perhitungan uji perbedaan skor pretes siswa KAM tinggi, sedang, dan rendah antara kedua kelas eksperimen disajikan pada Tabel 6.

Berdasarkan Tabel 6, nilai Sig. lebih besar dari nilai $\alpha=0,05$ sehingga $\mathrm{H}_{0}$ diterima. Hal ini bermakna bahwa pada setiap kategori KAM siswa, rata-rata skor pretes kemampuan penalaran matematis siswa kelas PBM tidak 
berbeda signifikan dengan rata-rata skor pretes kemampuan penalaran matematis siswa kelas PPT. Kesimpulannya adalah siswa pada kelas PBM dan PPT memiliki kemampuan awal penalaran matematis yang tidak berbeda signifikan pada semua kategori KAM siswa.

Tabel 6. Hasil Uji Perbedaan Skor Pretes

\begin{tabular}{|l|c|c|c|c|}
\hline \multirow{2}{*}{ KAM } & \multicolumn{3}{|l}{$\begin{array}{l}\text { t-test for Equality } \\
\text { of Means }\end{array}$} & \multirow{2}{*}{ Kesimpulan } \\
\cline { 2 - 4 } & df & Stat & Sig. & \\
\hline Tinggi & 10 & $-0,495$ & 0,631 & $\mathrm{H}_{0}$ diterima \\
\hline Sedang & 49 & 1,634 & 0,109 & $\mathrm{H}_{0}$ diterima \\
\hline Rendah & 11 & 0,477 & 0,642 & $\mathrm{H}_{0}$ diterima \\
\hline
\end{tabular}

Uji normalitas skor $N$-gain dihitung menggunakan uji One-Sampel KolmogorovSmirnov dengan nilai $\alpha=0,05$. Hasil perhitungan dapat dilihat pada Tabel 7.

Tabel 7. Hasil Uji Normalitas Skor $N$-gain

\begin{tabular}{|l|l|l|l|l|}
\hline \multirow{2}{*}{ KAM } & \multirow{2}{*}{ Kelas } & \multicolumn{2}{|c|}{$\begin{array}{c}\text { One-Sampel } \\
\text { Kolmogorov- } \\
\text { Smirnov }\end{array}$} & \multirow{2}{*}{ Kesimpulan } \\
\cline { 3 - 4 } & & Stat & Sig. & \\
\hline \multirow{2}{*}{ Tinggi } & PBM & 0,643 & 0,802 & $\mathrm{H}_{0}$ diterima \\
\cline { 2 - 5 } & PPT & 0,622 & 0,834 & $\mathrm{H}_{0}$ diterima \\
\hline \multirow{2}{*}{ Sedang } & PBM & 0,825 & 0,504 & $\mathrm{H}_{0}$ diterima \\
\cline { 2 - 5 } & PPT & 0,503 & 0,962 & $\mathrm{H}_{0}$ diterima \\
\hline \multirow{2}{*}{ Rendah } & PBM & 0,650 & 0,792 & $\mathrm{H}_{0}$ diterima \\
\cline { 2 - 5 } & PPT & 0,530 & 0,941 & $\mathrm{H}_{0}$ diterima \\
\hline
\end{tabular}

Berdasarkan Tabel 7, nilai Sig. seluruh kategori KAM pada kedua kelas lebih besar dari nilai $\alpha=0,05$ sehingga $\mathrm{H}_{0}$ diterima. Hal ini bermakna bahwa data skor $\mathrm{N}$-gain kemampuan penalaran matematis siswa pada semua kategori KAM di kedua kelas eksperimen berdistribusi normal.

Uji homogenitas dilakukan menggunakan uji homogeneity of variances (levene statistic) dengan nilai $\alpha=0,05$. Hasil perhitungan uji homogenitas disajikan pada tabel berikut.

Tabel 8. Hasil Uji Homogenitas Skor $N$-gain

\begin{tabular}{|l|l|l|l|}
\hline KAM & $\begin{array}{l}\text { Levene } \\
\text { Statistic }\end{array}$ & Sig. & Kesimpulan \\
\hline Tinggi & 1,571 & 0,239 & $\mathrm{H}_{0}$ diterima \\
\hline Sedang & 0,876 & 0,354 & $\mathrm{H}_{0}$ diterima \\
\hline Rendah & 0,31 & 0,587 & $\mathrm{H}_{0}$ diterima \\
\hline
\end{tabular}

Berdasarkan Tabel 8, nilai Sig. setiap kategori KAM lebih besar dari nilai $\alpha=0,05$ sehingga $\mathrm{H}_{0}$ diterima. Hal ini bermakna bahwa data skor $N$-gain kemampuan penalaran matematis pada kategori KAM tinggi, sedang, dan rendah masing-masing memiliki variansi yang homogen.

Uji selanjutnya menggunakan uji statistik parametrik, yaitu uji-t dengan nilai $\alpha=0,05$. Hasil perhitungan uji perbedaan skor $N$-gain siswa KAM tinggi, sedang, dan rendah antara kedua kelas eksperimen disajikan pada tabel berikut.

Tabel 9. Hasil Uji Perbedaan Skor N-gain

\begin{tabular}{|c|c|c|c|c|}
\hline \multirow{2}{*}{ KAM } & \multicolumn{3}{|c|}{ t-test for Equality of } & \multirow{2}{*}{ Keans } \\
\cline { 2 - 5 } & df & Stat & Sig. & \\
\hline Tinggi & 10 & 2,032 & 0,070 & $\mathrm{H}_{0}$ diterima \\
\hline Sedang & 48 & 4,606 & 0,000 & $\mathrm{H}_{0}$ ditolak \\
\hline Rendah & 11 & 1,839 & 0,093 & $\mathrm{H}_{0}$ diterima \\
\hline
\end{tabular}

Berdasarkan Tabel 9, nilai Sig. pada kategori KAM tinggi dan rendah lebih besar dari nilai $\alpha=0,05$ sehingga $\mathrm{H}_{0}$ diterima. Hal ini bermakna bahwa peningkatan kemampuan penalaran matematis siswa KAM tinggi dan KAM rendah antara kelas PBM dengan kelas PPT tidak berbeda signifikan. Sedangkan pada kategori KAM sedang, nilai signifikansinya lebih kecil dari nilai $\alpha=0,05$ sehingga $\mathrm{H}_{0}$ ditolak. Artinya terdapat perbedaan signifikan peningkatan kemampuan penalaran matematis antara siswa KAM sedang kelas PBM dengan siswa KAM sedang kelas PPT. Dengan demi kian dapat disimpulkan bahwa terdapat perbedaan signifikan peningkatan kemampuan penalaran matematis antara kelas PBM dan kelas PPT pada siswa dengan kategori KAM sedang.

Berdasarkan hasil penelitian yang dipero leh, pada setiap kategori KAM, peningkatan kemampuan penalaran matematis siswa yang memperoleh pembelajaran berbasis masalah lebih tinggi dibandingkan peningkatan kemam puan penalaran matematis siswa yang mendapat pembelajaran penemuan terbimbing. Menurut peneliti hal ini terjadi karena dua hal. Pertama, pada pembelajaran berbasis masalah, siswa diberi masalah dan tidak diberi arahan kemana mereka akan memulai langkah penyelesaiannya. Siswa diberi kesempatan sebesar-besarnya untuk menentukan proses penyelesaian masalah. Mereka berdiskusi bersama teman kelompok menentukan apa yang harus mereka lakukan. Jika mereka menemukan kesulitan baru kemudian guru memberikan bimbingan. Sedangkan pada pembelajaran penemuan terbimbing, siswa menemukan sendiri konsep 
pembelajaran melalui LKS yang disediakan guru. Pada LKS, telah ada pertanyaanpertanyaan terbimbing. Meskipun menemukan sendiri konsep melalui LKS, tapi sebenarnya siswa telah mendapatkan arahan melalui LKS tentang apa yang harus mereka lakukan. Memperhatikan proses pembelajaran antara PBM dan PPT, tampaknya siswa belajar dan terlibat lebih banyak pada pembelajaran berbasis masalah dibandingkan pada pembelajaran penemuan terbimbing. Oleh karena siswa belajar dan terlibat lebih banyak pada pembelajaran berbasis masalah, maka siswa memperoleh hasil yang lebih baik.

Kedua, pada pembelajaran berbasis masalah, siswa memulai pembelajaran dengan masalah yang diberikan guru. Masalah yang dimaksud disini adalah soal-soal matematika. Soal yang diberikan merupakan soal yang relatif sulit dan kontekstual. Dari soal yang diberikan ini, siswa menyelesaikan masalah dan menemu kan konsep matematika terkait materi yang sedang dipelajari. Sedangkan pada pembelajaran penemuan terbimbing, siswa belajar melalui LKS. LKS ini berisi pernyataan dan pertanyaan terbimbing untuk siswa menemukan konsep. Lalu diakhir pembelajaran siswa mengerjakan soal latihan. Jadi, fokus pada pembelajaran penemuan terbimbing adalah penemuan konsep, sedangkan pada pembelajaran berbasis masalah adalah penyelesaian masalah berupa soal-soal. Jika dilihat dari proses pembelajaran, siswa yang mendapat pembelajaran berbasis masalah lebih terbiasa dalam mengerjakan soal-soal, khu susnya soal-soal yang relatif sulit. Sehingga ketika diberikan soal tes, siswa yang mendapat pembelajaran berbasis masalah relatif merasa lebih mudah dibandingkan siswa yang mendapat pembelajaran penemuan terbimbing. Hal inilah yang diduga menjadi penyebab mengapa kemam puan penalaran matematis siswa yang mendapat pembelajaran berbasis masalah lebih baik diban dingkan kemampuan penalaran matematis siswa yang mendapat pembelajaran penemuan terbimbing.

Berdasarkan uji statistik yang dilakukan, perbedaan signifikan peningkatan kemampuan penalaran matematis antara kelas PBM dan PPT terjadi pada siswa dengan kategori KAM sedang. Sedangkan pada kategori KAM rendah dan tinggi tidak terdapat perbedaan yang signifikan. Menurut analisa peneliti, hal ini terjadi karena model pembelajaran berbasis masalah dan pembelajaran penemuan terbim bing pada dasarnya sama-sama menekankan keaktifan belajar siswa. Karena karakter yang mirip ini, PBM dan PPT tidak memiliki pengaruh yang cukup kuat pada siswa dengan kategori KAM tinggi dan rendah.

Pada siswa dengan kategori KAM tinggi, siswa memiliki kemampuan matematika yang memang baik sejak awal. Siswa dengan karakter seperti ini memang mudah dalam memahami materi matematika. Sehingga peran sebuah model pembelajaran tidak begitu berpengaruh kepada siswa-siswa pada kategori ini. Model pembelajaran apapun yang digunakan, siswa dengan kemampuan tinggi relatife mampu memahami materi dengan baik. Oleh sebab itu tidak terdapat perbedaan signifikan peningkatan kemampuan penalaran matematis pada siswa KAM tinggi antara kelas PBM dan kelas PPT.

Pada siswa KAM rendah terjadi hal sebaliknya. Siswa pada kategori ini sulit mema hami materi matematika. Ketika diberikan pem belajaran dengan model tertentu maka kemam puan siswa KAM rendah tidak meningkat signifikan. Hal ini menyebabkan peningkatan kemampuan penalaran matematis pada siswa KAM rendah tidak berbeda signifikan antara kelas PBM dan PPT. Perbedaan signifikan antara siswa KAM tinggi dan rendah bisa saja terjadi jika seandainya model pembelajaran yang digunakan memiliki perbedaan yang mendasar.

Pada siswa kategori KAM sedang, siswa berada pada kondisi pertengahan antara siswa kemampuan rendah dan kemampuan tinggi. Siswa pada kategori ini sangat bergantung pada faktor luar yang bisa mempengaruhi hasil belajar mereka. Perbedaan perlakuan pada siswa kelompok ini akan memberikan hasil yang ber beda pula. Oleh karena itu perbedaan pembela jaran yang diberikan berupa PBM dan PPT memberikan peningkatan kemampuan penalaran matematis yang berbeda signifikan.

\section{KESIMPULAN}

Berdasarkan hasil analisis dan pem bahasan yang telah dilakukan, kesimpulan yang diperoleh dari penelitian ini adalah terdapat perbedaan signifikan peningkatan kemampuan penalaran matematis antara yang memperoleh pembelajaran berbasis masalah dengan yang memperoleh pembelajaran penemuan terbim bing pada siswa dengan kemampuan awal matematis sedang. Pada siswa dengan kemam puan awal matematis tinggi dan rendah, tidak 
terdapat perbedaan signifikan peningkatan kemampuan penalaran matematis antara yang memperoleh pembelajaran berbasis masalah dengan yang memperoleh pembelajaran penemuan terbimbing.

\section{DAFTAR PUSTAKA}

Ajai, Imoko and O'kwu, Emmanuel. 2013. Comparison of the Learning Effectiveness of Problem-Based Learning (PBL) and Conventional Method of Teaching Algebra. Journal of Education and Practice, 4 (1), 131-136.

Armiati. 2011. Peningkatan Kemampuan Penalaran Matematis, Komunikasi Matematis dan Kecerdasan Emosional Mahasiswa melalui Pembelajaran Berbasis Masalah. (Disertasi). Sekolah Pascasarjana, Universitas Pendidikan Indonesia, Bandung.

Badan Standar Nasional Pendidikan. 2006. Standar isi. Jakarta.

Buhaerah. 2011. Pembelajaran Berbasis Masalah untuk Meningkatkan Kemam puan Penalaran Matematis Siswa SMP. Gamatika, Volume 2, Nomor 1, hlm. 5261.

Cohen, Manion and Morrison, Keith. 2007. Research Methods in Education. $6^{\text {th }}$ Edition. Routledge, London.

David E. Meltzer. 2002. The Relationship Between Mathematics Preparation and Conceptual Learning Gain in Physics: A possible "hidden variable" in diagnostics pretest scores. American Journal of Physics, 70 (12), 1259-1268.

Haryani Hasibuan, Irwan, dan Mirna. 2014. Penerapan Metode Penemuan Terbimbing pada Pembelajaran Matematika Kelas XI IPA SMAN 1 Lubuk Alung. Jurnal Pendidikan Matematika, Volume 3, Nomor 1, hlm. 38-44.

Jajang Rahmatudin. 2013. Penerapan Model Pembelajaran Search, Solve, Create, and Share untuk Meningkatkan Kemampuan Penalaran Matematis dan Self Concept Siswa SMP Negeri 1 Kedawung. (Tesis). Sekolah Pascasarjana Universitas Pendidikan Indonesia, Bandung.

Kramarski and Mevarech, Zemira. 2003. Enhancing Mathematical Reasoning in the Classroom: The Effects Of Cooperative Learning And Metacognitive Training.
American Educational Research Journal, 40 (1), 281-310.

Leo Adhar Effendi. 2012. Pembelajaran Matematika dengan Metode Penemuan Terbimbing untuk Meningkatkan Kemampuan Representasi dan Pemecahan Masalah Matematis Siswa SMP. Jurnal Penelitian Pendidikan, Volume 12, Nomor 2, hal. 1-12.

NCTM. 1989. Curriculum and Evaluation Standards for School Mathematics. NCTM, Reston.

NCTM. 2000. Principles and Standards for School Mathematics. NCTM, Reston.

Nurcholis. 2013. Implementasi Metode Penemuan Terbimbing untuk Mening katkan Hasil Belajar Siswa pada Penarikan Kesimpulan Logika Mate matika. Jurnal Elektronik Pendidikan Matematika Tadulako, Volume 1, Nomor 1, hlm. 32-42.

Padmavathy and Mareesh K. 2013. Effectiveness of Problem Based Learning in Mathematics. International Multi disciplinary e-Journal, 2 (1), 45-51.

Richard R. Hake. 1999. Analyzing Change/Gain Scores. Diakses pada 19 Januari 2015. [Online]. Tersedia di http://www. Phy sics. indiana. edu/ sdi/AnalyzingChangeGain. pdf.

Sentosa. 2013. Peningkatan Kemampuan Penalaran, Komunikasi Matematis serta Kemandirian Belajar Siswa Sekolah Menengah Pertama melalui Pembelajaran Eksploratif. (Tesis). Sekolah Pasca sarjana, Universitas Pendidikan Indo nesia, Bandung.

Sri Purwatiningsi. 2013. Penerapan Metode Penemuan Terbimbing untuk Mening katkan Hasil Belajar Siswa pada Materi Luas Permukaan dan Volume Balok. Jurnal Elektronik Pendidikan Matematika Tadulako, Volume 1, Nomor 1, hlm. 5363.

Suharsimi Arikunto. 2013. Dasar-dasar Evaluasi Pendidikan. Edisi Kedua. Bumi Aksara, Jakarta.

Tatang Herman. 2007. Pembelajaran Berbasis Masalah untuk Meningkatkan Kemam puan Berpikir Matematis Tingkat Tinggi Siswa Sekolah Menengah Pertama. Educationist, Volume 1, Nomor 1, hlm. 47-56. 
Turmudi. 2008. Landasan Filsafat dan Teori Pembelajaran Matematika: Berparadigma Eksploratif dan Investigatif. PT Leuser Cita Pustaka, Jakarta.

Utari Sumarmo. 2013. Kumpulan Makalah: Berpikir dan Disposisi Matematik serta Pembelajarannya. Jurusan Pendidikan Matematika, FPMIPA UPI, Bandung.

Wahyudin. 2008. Pembelajaran \& Model-model Pembelajaran: Pelengkap untuk
Meningkatkan Kompetensi Pedagogis para Guru dan Calon Guru Profesional. Mandiri, Bandung.

Yuniati. 2010. Meningkatkan Kemampuan Pemahaman dan Penalaran Matematik Siswa Sekolah Menengah Pertama dengan Pembelajaran Problem Posing. (Tesis). Sekolah Pascasarjana, Universitas Pendidikan Indonesia, Bandung. 